\title{
Cytotoxic Effect and Constituent Profile of Alkaloid Fractions from Ethanolic Extract of Ficus septica Burm. f. Leaves on T47D Breast Cancer Cells
}

\author{
Agung Endro Nugroho' ${ }^{1 *}$, Fiki Fatihah Akbar ${ }^{1}$, Anggie Wiyani ${ }^{1}$, Sudarsono ${ }^{2}$
}

\begin{abstract}
The study aimed to investigate the profile of alkaloids in two ethyl acetate soluble fractions, namely fractions A and B from an ethanolic extract of Ficus septica leaves and cytotoxic effect on T47D breast cancer cells. Preparation of both fractions involved maceration of leaves with $70 \%$ (v/v) ethanol, filtration with $\mathrm{Al}_{2} \mathrm{O}_{3}$, precipitation with $0.1 \mathrm{~N} \mathrm{HCl}$, Mayer reagent, and $0.1 \mathrm{~N} \mathrm{NaOH}$, and also partition with ethyl acetate. Qualitative thin layer chromatography (TLC) was conducted to determine the profile of alkaloids in the two fractions, using alkaloid specific reagents such as Dragendorff, sodium nitrite, and Van Urk-Salkowski. Cytotoxic effects of both fractions on T47D cells were evaluated using MTT assay with a concentration series of 1.56; 3.12; 6.25; 12.5; 25 and $50 \mu \mathrm{g} / \mathrm{mL}$. The TLC test showed that fractions A and B contained alkaloids with Rx values of 0.74 and 0.80 for fraction $A$ and $0.74,0.84,0.92$ for fraction $B$ with regard to yohimbine using the mobile phase of n-buthanol:glacial acetic acid:distilled water (3:1:1 v/v/v). Moreover, an indole alkaloid was detected with $R x$ values of 0.80 and 0.84 , respectively. Fractions $A$ and $B$ exhibited high cytotoxic effects on T47D cells with IC50 values of 2.57 and $2.73 \mu \mathrm{g} / \mathrm{mL}$, respectively. In conclusion, overall the results of this study showed that fractions of Ficus septica contain alkaloids including indole alkaloid or its derivatives and possess a cytotoxic effect on T47D cells. This research supports the idea that alkaloids in $F$. septica have anticancer activity.
\end{abstract}

Keywords: Ficus septica Burm. f. - T47D breast cancer cells - cytotoxic activity - alkaloids

Asian Pac J Cancer Prev, 16 (16), 7337-7342

\section{Introduction}

Cancer is a disease associated with uncontrolled growth and spread of abnormal cells (American Cancer Society, 2014). The abnormal cells are characterized with an alteration in cell differentiation and cell communication with its extracellular environment (Pusztai et al., 1995). With its characteristics, cancer has become one of the leading causes of morbidity and mortality in the world. According to a World Health Organization (WHO) global report, number of new cancer cases reached 14.1 million, and 8.2 million for cancer-related deaths in 2012 (Ferlay et al., 2013). Therefore, looking at this high numbers, numerous attempts have been done in order to discover new treatment for cancer. The attempts include studies on chemotherapy agents from medicinal plants.

Previous study reported that alkaloid compounds in Awar-awar (Ficus septica) are potential as a cytotoxic agent (Wu et al., 2002; Lansky et al., 2008). Ethanolic extract of Ficus septica Burm. f. leaves exhibited a cytotoxic effect on human T47D breast cancer cell line with $\mathrm{IC}_{50}$ value of $13.0 \mu \mathrm{g} / \mathrm{mL}$ (Pratama, 2010). The ethanolic extract of $F$. septica leaves was gradually fractionated to provide some fractions. Among the fractions, n-hexane insoluble fraction and ethyl acetate soluble fraction exhibited most potent cytotoxic effect on T47D cell line with $\mathrm{IC}_{50}$ value of 9.3 and $13.7 \mu \mathrm{g} /$ $\mathrm{mL}$, respectively (Nugroho et al., 2011a). These fractions exhibited synergistic effects with doxorubicin on T47D cell line (Nugroho et al., 2012a; Nugroho et al., 2013a). The fraction also exhibited immunomodulatory effect in the in vitro and in vivo studies (Nugroho et al., 2012b; Nastiti et al., 2014).

Perceiving alkaloid profile of F. septica leaves is advantageous in chemotherapy agent, and anticancer drug discovery for it may serve as a leading compound. To date, various studies in regard to cytotoxic effect of $F$. septica leaves have not investigated the profile of its alkaloid compounds, despite its cytotoxic effect has been recognized (Wu et al., 2002). Based on previous positive results on ethyl acetate soluble fraction, thus the present study investigates the profile of alkaloids in the ethyl acetate fraction with water-soluble components (fraction A) and ethyl acetate fraction with ethanol-soluble 
Agung Endro Nugroho et al

components (fraction B) from ethanolic extract of $F$. septica leaves and their cytotoxic effect on human T47D breast cancer cell line.

\section{Materials and Methods}

\section{Materials}

F. septica leaves were collected from Sumber Arum, Moyudan, Yogyakarta Indonesia on July 2013 and were identified at Laboratory of Pharmacognosy, Department of Pharmaceutical Biology, Faculty of Pharmacy, Universitas Gadjah Mada, Indonesia. The voucher specimen was deposited in herbarium of the department. Materials for alkaloids profile determination were yohimbine hydrochloride (catalog number Y3125) (Sigma-Aldrich, Germany), and silica gel $60 \mathrm{~F}_{254}$ Thin Layer Chromatography (TLC) plate (Merck, Germany). Mayer reagent, Dragendorff spray reagent, sodium nitrite $\left(\mathrm{NaNO}_{2}\right)$ spray reagent, and Van Urk-Salkowski spray reagent were obtained from the Department of Pharmaceutical Biology, Faculty of Pharmacy, Universitas Gadjah Mada, Indonesia. Materials for assay were dimethyl sulfoxide (DMSO) (Gibco Invitrogen, USA), doxorubicin (Kalbe Farma, Indonesia), and [3 - (4,5-dimethylthiazol-2-yl) -2,5-diphenyltetrazolium bromide] (MTT) (Bio Basic, Canada). The final DMSO concentration was $1 \%$. Doxorubicin was used for in vitro experiment by diluting the stock solution to provide the final desired concentration. Microplate reader (Bio-Rad microplate reader Benchmark serial no. 11565) was used to measure the absorbance at $595 \mathrm{~nm}$ for the MTT colorimetric reaction in the cytotoxicity assay.

\section{Preparation of extract}

Dried leaves of $F$. septica were grinded to form a coarse powder $(500 \mathrm{~g})$. The coarse powder was macerated with total of $5 \mathrm{~L} 70 \%$ ethanol $(1: 10 \mathrm{w} / \mathrm{v})$. Firstly, powder was macerated with $2.5 \mathrm{~L}(1: 5 \mathrm{w} / \mathrm{v})$ ethanol for 24 hours. Subsequently, the filtrate was collected, while the residue was re-macerated. Re-maceration of residue used $70 \%$ ethanol with a ratio of $1: 2.5 \mathrm{w} / \mathrm{v}$ for 24 hours. The remaceration was done twice. All filtrates were collected and evaporated for 12 hours to form a viscous ethanolic extract with a weight of $40 \mathrm{~g}$. To provide extract's fractions, the viscous ethanolic extract was diluted with hot distilled water. The distilled water have $\mathrm{pH}$ value of 2-3 after addition with $0.1 \mathrm{~N} \mathrm{HCl}$. Secondly, the diluted extract was filtrated through a column packed with $83.12 \mathrm{~g}$ of aluminium (III) oxide $\left(\mathrm{Al}_{2} \mathrm{O}_{3}\right)(1: 2 \mathrm{w} / \mathrm{w})$. Filtration was replicated twice. Each replication used new $\mathrm{Al}_{2} \mathrm{O}_{3}$ powder with the same weight. Finally, filtrate was collected and evaporated on a waterbath yielding filtrate A. Whilst, unfiltrated residue was collected and extracted with $96 \%$ ethanol. Filtrate was collected and evaporated on a waterbath yielding filtrate $\mathrm{B}$.

\section{Preparation of extract's fractions}

Separately, filtrate A and filtrate B were added with $0.1 \mathrm{~N} \mathrm{HCl}$ drops until a final $\mathrm{pH}$ ranging 2 to 3 . Mayer reagent was added to each test solution until alkaloids precipitate is formed. Each precipitate was obtained after centrifugation. Its supernatant was removed while alkaloids precipitate remained on the bottom of each test tube. Each tube was thoroughly added with $0.1 \mathrm{~N} \mathrm{HCl}$ to dissolve the precipitate. The tube was placed in an ultrasonicator bath to enhance the dissolving process. Each solution was added with $0.1 \mathrm{~N} \mathrm{NaOH}$ to reach a final $\mathrm{pH}$ value of 8-9. Each solution was partitioned with ethyl acetate yielding ethyl acetate soluble fraction and insoluble fraction. Both ethyl acetate soluble fractions were recalled as fraction $\mathrm{A}$ and fraction $\mathrm{B}$.

\section{Determination of alkaloids profile}

The determination of alkaloids profile was performed with a Thin Layer Chromatography (TLC) assay. As the stationary phase, silica gel $60 \mathrm{~F}_{254}$ TLC plates were used. Mobile phase was a solvent system of n-buthanol : acetate acid glacial: distilled water with a ratio of $(3: 1: 1 \mathrm{v} / \mathrm{v} / \mathrm{v})$. Yohimbine hydrochloride (Sigma-Aldrich, Germany) was as used an alkaloid standard. A $10 \mu \mathrm{l}$ each fraction (fraction A and B) was spotted on separated TLC plates as samples. A $4 \mu \mathrm{l}$ of yohimbine was spotted on each plate as a standard of alkaloid. Following the separation processes, spraying agents were used on separated TLC plates to determine alkaloids profile. The spraying agents were Dragendorff, $\mathrm{NaNO}_{2}$, and Van Urk-Salkowski. Alkaloids profile was determined based on $\mathrm{Rx}$ value. This value was measured using the following formula:

$$
\mathrm{Rx}=\frac{\text { distance traveled by sample from original line }(\mathrm{cm})}{\text { distance traveled by standard from original line }(\mathrm{cm})}
$$

\section{T47D cell culture}

Human T47D breast cancer cell line was obtained from Laboratory of Parasitology, Faculty of Medicine, Universitas Gadjah Mada, Indonesia and grown in Roswell Memorial Park Institute (RPMI) medium containing $10 \%$ fetal bovine serum (Gibco, USA), 2\% penicillinstreptomycin (Gibco, USA), and fungizone $0.5 \%$ (Gibco, USA) in a flask in a humidified atmosphere $\left(5 \% \mathrm{CO}_{2}\right)$ at $37^{\circ} \mathrm{C}$.

\section{Cytotoxicity assay}

T47D cells viability was assessed using a MTT (Bio Basic, Canada) colorimetric assay. The cells were cultured in 96 -well plates and each well contained $5 \times 10^{4}$ cells $/ 100$ $\mu \mathrm{L}$. The culture cells were incubated in a humidified incubator at $37^{\circ} \mathrm{C}$ in an atmosphere of $5 \% \mathrm{CO}_{2}$ for 24 hours. Cell confluence or crowding of cells in the plate was $80 \%$, counted with hemocytometer and cell counter. After 24 hours incubation, culture medium was discarded. The cells were treated by either fractions of F. septica or Doxorubicin (control group), and then incubated for 24 hours. The concentrations of the fractions were 1.56; 3.12; $6.25 ; 12.5 ; 25 ; 50 \mu \mathrm{g} / \mathrm{mL}$ in cell culture. After incubation, the cells were incubated with $0.5 \mathrm{mg} / \mathrm{mL} \mathrm{MTT} \mathrm{for} 4$ hours in $37^{\circ} \mathrm{C}$. Viable cells react with MTT to produce purple formazan crystals. After 3-4 hours, the 10\% SDS stopper solution (Gibco, USA) in $0.1 \mathrm{~N} \mathrm{HCl}$ (Merck, Germany) was added to dissolve the formazan crystal. The cells were then incubated for 24 hours at room temperature and protected from light. After incubation, the 96-well plate 
was shaken using a horizontal shaker for homogenization, and the absorbance was measured by a microplate reader (Bio-Rad, Tokyo, Japan) at $595 \mathrm{~nm}$.

\section{Data analysis}

Experimental data from the cytotoxicity assay was MTT absorbance. Cell absorbance holds a positive correlation with the number of viable cells. Then, cell absorbance was converted to percentage of viable cells by this following equation:

$$
\text { Cells viability }(\%)=\frac{(\mathrm{B}-\mathrm{C})}{(\mathrm{A}-\mathrm{C})} \times 100 \%
$$

Where A, B, and C stand for absorbance of control group, treatment group, and cell culture medium, respectively. The acquired data was plotted on a graph expressing the relation between concentrations of fractions and cell viability.

Potency of cytotoxic effect was represented by $\mathrm{IC}_{50}$ value. The value of $\mathrm{IC}_{50}$ expresses a concentration of the fractions which can give a reduction to cell viability by $50 \%$. $\mathrm{IC}_{50}$ was calculated using probit analysis based on linear regression relationship between the logarithm of concentration of fraction (independent variable) and the percentage of cell viability (dependent variable).

\section{Results}

Fractions of F. septica leaves and their alkaloids profile

Two different fractions were provided according to the scheme in figure 1. Using the alkaloids TLC identification method from Spangenberg et al. (2008) with Dragendorff spray and sodium nitrite spray reagents, the alkaloids spots were well-visualized. Two consecutive sprays with Dragendorff and sodium nitrite reagents was able to enhance the visualization of the alkaloids spots for its discolored background. Prior to the sodium nitrite spray,

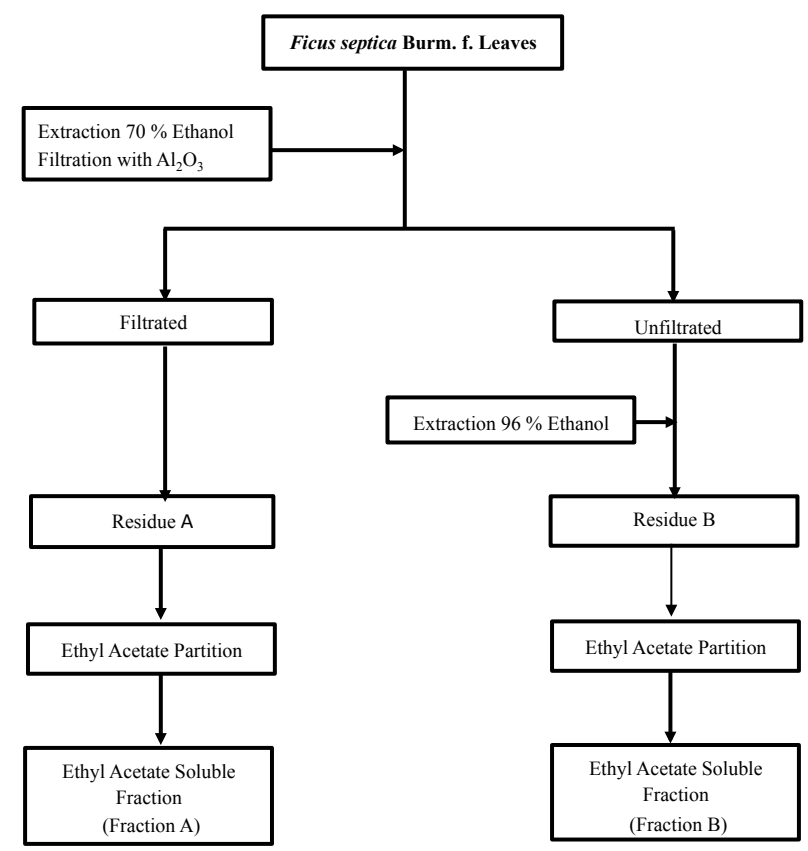

Figure 1. Scheme of Procedures for Obtaining Fraction A and Fraction B from Ficus Septica Burm. f. Leaves the alkaloids spots were less visualized. The color of the spots was orange, similar to the background. The alkaloids spots seen after spraying are shown in Figure 2. There were six alkaloids spots, two spots of fraction A and four spots of fraction $\mathrm{B}$.

The result of this TLC alkaloid identification was in alignment with prior alkaloids precipitation test. The alkaloids precipitation test was performed using Mayer and Dragendorff reagents and giving positive results. Both reagents were added to test solutions. Precipitate was formed on both test solutions from both reagents. Precipitate gave cream and reddish brown color with Mayer and Dragendorff reagents, respectively. The precipitate color indicated presence of alkaloids in both fractions (Harborne, 1973; Nelima et al., 2011). A further investigation on alkaloids profile was performed with a Van Urk-Salkowski test developed by Ehmann (1977). Figure 2 showed the visualized spots. There were two spots visualized, one for each fraction. We can conclude that both fractions contain alkaloids. Alkaloids profile is determined with $\mathrm{Rx}$ value in regard to yohimbine. The $\mathrm{Rx}$ values of the spots were 0.80 and 0.84 for fraction $A$ and fraction $B$, respectively.

Effect of fractions of F. septica leaves on T47D cells viability

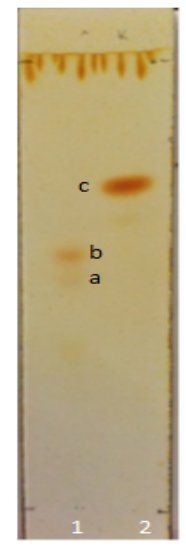

(A)

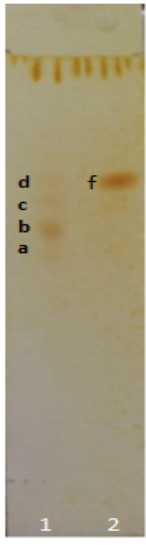

(B)

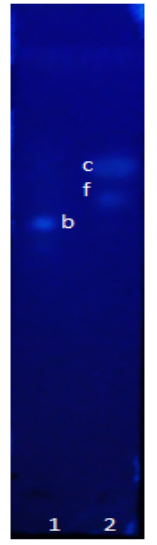

(C)

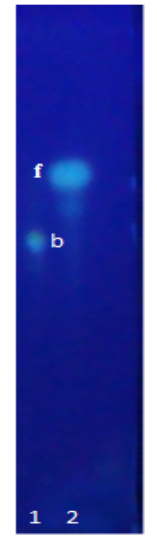

(D)
Figure 2. TLC profiles of Fraction A, Fraction B, and Standard using n-Buthanol: Glacial Acetic Acid: Distilled Water (3:1:1 v/v/v) as Mobile Phase after Dragendorff-sodium Nitrite Spraying and Van UrkSalkowski Spraying. Plate (1): lane 1 is fraction A and lane 2 is standard. TLC plate was visualized after Dragendorff-sodium nitrite spraying under visible light. There were two spots found (a $\&$ b). These spots indicated presence of alkaloids. Its Rx values were 0.74 and 0.80 respectively. Plate (2): lane 1 is fraction $B$ and lane 2 is standard. TLC plate was visualized after Dragendorffsodium nitrite spraying under visible light. There were four spots found (a, b , c, d). These spots indicated presence of alkaloids. Its Rx values were $0.74 ; 0.84 ; 0.93 ; 1$ respectively. Plate (3): lane 1 is fraction A and lane 2 is standard. TLC plate was visualized after Van Urk-Salkowski spraying under UV $366 \mathrm{~nm}$ light. There was one spot found (b). This spot indicated presence of indole alkaloids or its derivatives. Its Rx value was 0.80 . Plate (4): lane 1 is fraction B and lane 2 is standard. TLC plate was visualized after Van Urk-Salkowski spraying under UV $366 \mathrm{~nm}$ light. There was one spot found (b). This spot indicated presence of indole 


\begin{tabular}{ccc}
\hline Concentration $(\boldsymbol{\mu g} / \mathbf{m L})$ & Fraction A & Fraction B \\
\hline $\mathbf{1 . 5 6}$ & $51.632 \pm 1.690$ & $52.148 \pm 0.188$ \\
$\mathbf{3 . 1 2}$ & $48.729 \pm 0.709$ & $50.408 \pm 1.610$ \\
$\mathbf{6 . 2 5}$ & $42.993 \pm 0.930$ & $42.741 \pm 0.518$ \\
$\mathbf{1 2 . 5 0}$ & $18.132 \pm 1.158$ & $21.479 \pm 2.403$ \\
$\mathbf{2 5}$ & $2.461 \pm 0.664$ & $1.305 \pm 0.331$ \\
$\mathbf{5 0}$ & $2.059 \pm 0.329$ & $0.381 \pm 0.144$ \\
\hline
\end{tabular}

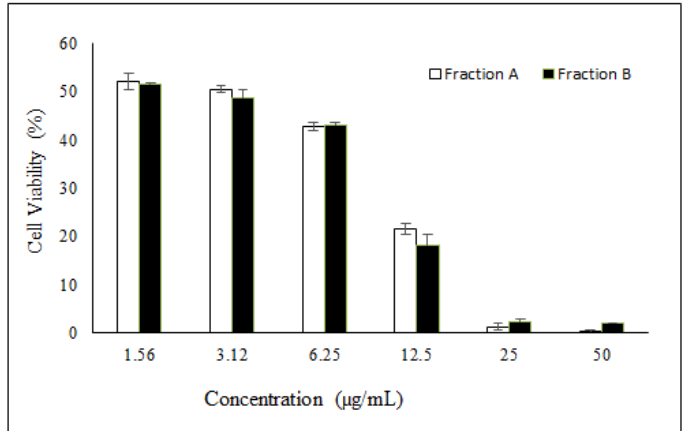

Figure 3. Effect of Fraction A and Fraction B on T47D Cells Viability using MTT Method. T47D cells were incubated with $1.56 ; 3.12 ; 6.25 ; 12.50 ; 25 ; 50 \mu \mathrm{g} / \mathrm{mL}$ of both Fraction A and B for 24 hours at $37 \mathrm{oC}$. Data shown comes from two replication. Data are expressed as (mean \pm SEM).
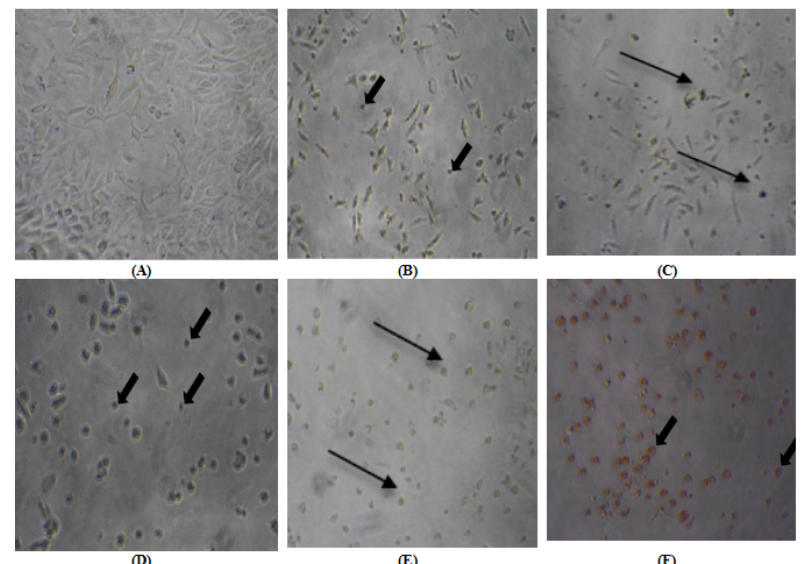

Figure 4. Effect of Fraction A and Fraction B on Cell Viability of T47D Cells Tested by MTT Method. Cell morphology was observed under microscope after incubation with (A) vehicle control; (B) Fraction A $12.5 \mu \mathrm{g} / \mathrm{mL}$; (C) Fraction B $12.5 \mu \mathrm{g} / \mathrm{mL}$; (D) Fraction A $50 \mu \mathrm{g} / \mathrm{mL}$; (E) Fraction B $50 \mu \mathrm{g} /$ $\mathrm{mL} ;(\mathrm{F})$ Doxorubicin as positive control. Dead cells are pointed by black arrows

Figures 3-4 show the effect of fraction $A$ and fraction $\mathrm{B}$ in their concentration series on T47D cells viability for 24 hours incubation. Fraction A and fraction B affected T47D cells viability by inhibiting cell growth and reducing the number of viable cells. In the study, fraction A could decrease the cell viability in concentration-dependent manner. Highest concentration of fraction A $(50 \mu \mathrm{g} / \mathrm{mL})$ could inhibit cell growth resulting in $2.059 \pm 0.329 \%$ cell viability. Concentrations of fraction $\mathrm{B}$ also decreased the cell viability in concentration-dependent manner. Fraction $\mathrm{B}$ on its highest concentration $(50 \mu \mathrm{g} / \mathrm{mL})$ could inhibit cell growth and left $0.381 \pm .0 .144 \%$ viable cells. IC $_{50}$ values of fraction A and fraction B were $2.57 \mu \mathrm{g} / \mathrm{mL}$ and $2.73 \mu \mathrm{g} / \mathrm{mL}$, respectively.

Changes in T47D morphology are shown on Figure 4. Viable cells have a morphology similar to epithelial cells, while dead cells have smaller size. Dead cells changes morphologically to a circular form. The results indicated that fraction A and fraction B showed high cytotoxicity effect on T47D breast cancer cell line.

\section{Discussion}

Biodiversity of Indonesia is second largest in the world after Brazil including medicinal plants. Exploration of the medicinal plants is one approach in the discovery and development of drugs. The exploration includes pharmacological activities, herbal formulation, phytochemical studies etc (Nugroho et al., 2011b; Nugroho et al., 2011c; Nugroho et al., 2013b; Nugroho et al., 2014a-c). Since the cancer is the biggest killer in Indonesia, the studies of medicinal plants for the treatment of this disease become interesting (Sarmoko et al., 2014; Setiawati et al., 2014).

In present study, both fractions obtained from $F$. septica leaves exhibited a cytotoxicity effect on T47D cells. Reportedly, some alkaloids of $F$. septica showed cytotoxicity effect on HCT-9 cell line, NUGC cell line, and HONE-1 cell line (Damu et al., 2009). Some alkaloids of F. septica exhibited anti-inflammatory activity through Cyclooxygenase-2 (COX-2) and Inducible Nitric Oxide Synthase (iNOS) enzyme inhibition (Yang et al., 2006). Cancer cell activity may involve COX-2 and iNOS, thus the alkaloids have potential in anticancer activity.

Inevitably, the cytotoxicity effect comes from its phytochemical compounds. Results of previous studies indicated that F. septica contains alkaloids (Damu et al., 2005; Vital et al., 2010). Several alkaloids classes have been identified and known belong to alkaloids classes of indolizidine, phenanthroindolizidine, pyrolidine, caprophenone, and indole (Hegnauer, 1969; Gellert, 1982; Ueda et al., 2009; Nastiti, 2013). Intensive studies need to be conducted in order to identify remaining alkaloids in F. septica.

A specific cellular target or mechanism of action of alkaloids in F. septica have not been identified clearly (Yang, et al., 2006; Chemler, 2009). Several known alkaloids have been studied including tylophorine, antofine, and tylocrebrine. To date, their known mechanism of action varies from protein, DNA, and RNA synthesis inhibition (Chemler, 2009).

Alkaloids profile determined in this study is important for future studies. The determined alkaloids profile by the $\mathrm{Rx}$ value enables us to set a criteria we would like to achieve in future studies. By having the Rx values of alkaloids, it would be easier for future studies to determine the alkaloids profile they get, whether it is the same as presented in this study or not. The Rx value may help in isolation of the alkaloids in future studies.

Our study counts heavily on extracting as many alkaloids as possible. It was achieved by the extraction method which used acid-base extraction and ethyl acetate partition. Acid-base extraction is known as a method to perceive alkaloids compounds from crude extracts (Siwon, 1982). The alkaloid-containing extract was mixed with acid solution to convert the alkaloids into their salt form. Alkaloid salts are soluble in a polar solvent, however, their 
base form are soluble in a non-polar solvent. Filtration process through a column using $\mathrm{Al}_{2} \mathrm{O}_{3}$ functions to trap the inorganic ballast, phenolic compounds, some flavonoids etc (Haznagy-Radnai, 2007). Afterwards the tertiary amine alkaloids-containing fractions were dissolved in ethyl acetate. Several known alkaloids of F. septica are tertiary amine alkaloids. Thus, the ethyl acetate soluble fraction was used as the test solution in this study.

The present study has proved the acid-base extraction followed by ethyl acetate partition is an effective method to perceive alkaloids from $F$. septica with higher cytotoxicity effect on T47D cell lines in comparison to this of the fractions in previous studies. The fractions in this study exhibited lower valuese of $\mathrm{IC}_{50}$ which make them more potential to serve as an chemotherapeutic agent. We propose that the method and alkaloids profile in this study are important within the effort in discovering a chemotherapeutic agent from $F$. septica leaves. However, the molecular mechanism of the ethyl acetate soluble fraction still needs further investigations.

Ethyl acetate soluble fraction was yielded from acidbase extraction of ethanolic extract of $F$. septica leaves. The alkaloids-containing $F$. septica leaves exhibited a high cytotoxic effect on T47D cells. The fraction is potential to be developed as a chemotherapeutic agent in breast cancer therapy. Alkaloids profile contained in the fractions has been determined in the form of $\mathrm{Rx}$ value in regard to yohimbine. The data is crucial for further studies of extraction and isolation of alkaloids from $F$. septica leaves.

\section{Acknowledgements}

We send our highest gratitude to Directiorate of Higher Education (DIKTI) Ministry of Education, Indonesia through "Hibah Penelitian Kompetensi" Research Grant 2014 for financial support of the study.

\section{References}

American Cancer Society (2014). Cancer Facts \& Figures 2014. http://www.cancer.org/research/cancerfactsstatistics cancerfactsfigures2014/. 11 Mei 2014.

Chemler RS (2009). Phenanthroindolizidines and phenanthroquinolizidines: promising alkaloids for anticancer therapy. Curr Bioact Compd, 5, 2-19.

Damu AG, Kuo PC, Shi LS, et al (2009). Cytotoxic phenanthroindolizidine alkaloids from the roots of ficus septica. Planta Med, 75, 1152-6.

Damu AG, Kuo PC, Shi LS, et al (2005). Phenanthroindolizidine Alkaloids from the Stems of Ficus septica. J Nat Prod, 68, 1071-5.

Ehmann A (1977). The van urk-salkowski-salkowski reagent a sensitive and specific chromogenic reagent for silica gel thin-layer chromatographic detection and identification of indole derivatives. J Chromatogr, 132, 267-76.

Ferlay J, Soerjomataram I, Dikshit R, et al (2013). Cancer incidence and mortality worldwide: source, methods, and major patterns in GLOBOCAN 2012. Int J Cancer, 136, E359-86

Gellert E (1982). The Indolizidine Alkaloids. J Nat Prod, 45, 50-73.

Harborne BJ (1973). Phytochemical methods: a guide to modern techniques of plant analysis. Chapman \& Hall. New York.
Harwoko, Pramono S, Nugroho AE (2014b). Triterpenoidrich fraction of centella asiatica leaves and In vivo Antihypertensive Activity, Int Food Res J, 21, 149-54.

Haznagy-Radnai E (2007). Examination of the Volatile and Non-volatile Components of Hungarian Stachys Species. $\mathrm{PhD}$ Thesis. University of Szeged. Szeged.

Hegnauer R (1969). Chemotaxonomie der Pflanzen Volume 5. Birkhäuser Verlag, Basel.

Heyne K (1987). Tumbuhan Berguna Indonesia. Jilid II. badan litbang departemen kehutanan Indonesia. Jakarta.

Iskandar DT, Erdelen WR (2006). Conservation of amphibians and reptiles in indonesia: issues and problems. Amphib Reptile Conserv, 4, 60-87.

Lansky PE, Paavilainen HM, Pawlus, D (2008). Ficus spp. (fig): ethnobotany and potential as anticancer and antiinflammatory agents. J Ethnopharmacol, 119, 195-213.

Nastiti K, Sudarsono, Nugroho A (2014). Evaluation of in vitro immunomodulatory effects of fractions of Ficus septica burm. f. and their total flavonoid and phenolic contents. Int Food Res J, 21, 1981-7.

Nelima N, Devidas NG, Sudhakar M, et al (2011). A Preliminary Phytochemichal Investigation on the Leaves of Solanum xanthocarpum. Int J Res Ayurveda Pharm, 2, 845-50.

Nugroho AE, Ikawati M, Hermawan A, et al (2011a). Cytotoxic Effect of Ethanolic Extract Fractions of Indonesia Plant Ficus septica Burm. f. on human breast cancer T47D cell lines. Int J Phytomed, 3, 216-26.

Nugroho AE, Riyanto S, Sukari MA, et al (2011b). Anti-allergic effects of marmin, a coumarine isolated from aegle marmelos correa leaves: in vitro study. Int J Phytomed, 3, 84-97.

Nugroho AE, Anas Y, Arsito PN, et al (2011c). Effects of marmin: a compound isolated from aegle marmelos correa, on contraction of the guinea pig-isolated trachea. Pak J Pharm Sci, 24, 427-33.

Nugroho AE, Hermawan A, Putri DDP, et al (2012a). Synergistic effects of ethyl acetate fraction of Ficus septica burm. f. and doxorubicin chemotherapy on T47D human breast cancer cell line. J Chin Integr Med, 10, 1162-70.

Nugroho AE, Hermawan A, Nastiti K, et al (2012b). Immunomodulatory effect of hexane insoluble fraction of Ficus septica Burm. F. on doxorubicin-treated rats. Asian Pac J Cancer Prev, 13, 5785-90.

Nugroho AE, Hermawan A, Putri DDP, et al (2013a). Combinational effects of hexane insoluble fraction of Ficus septica Burm. F. and doxorubicin chemotherapy on T47D breast cancer cells. Asian Pac J Trop Biomed, 3, 297-302.

Nugroho AE, Lindawati NY, Herlyanti K, et al (2013b). Antidiabetic effect of a combination of andrographolide-enriched extract of andrographis paniculata (Burm f.) Nees and asiaticoside-enriched extract of centella asiatica L. in high fructose-fat fed rats. Indian J Exp Biol, 51, 1101-8.

Nugroho AE, Rais IR, Setiawan I, et al (2014a). Pancreatic effect of andrographolide isolade from andrographis paniculata. Pak J Biol Sci, 17, 22-31.

Nugroho AE, Kusumaramdani G, Prasetyo DP, et al (2014c). Anti-diabetic effect of a combination of $n$-hexane insoluble fraction of ethanlic extract of A. paniculata and other traditional medicine extracts in high-fructose-fat-fed rats. Int Food Res J, 21, 785-9.

Pratama RH (2010). Kombinasi ekstrak etanolik daun awar-awar (Ficus septica burm. f.) dengan doksorubisin dalam upaya peningkatan aktivitas sitotoksik doksorubisin dan induksi apoptosis pada sel kanker payudara T47D. Skripsi. Fakultas Farmasi Universitas Gadjah Mada. Yogyakarta.

Pusztai L, Lewis CE, Yap E (Eds.) (1995). Cell proliferation in cancer: regulatory mechanisms of neoplastic cell growth. Oxford University Press. Oxford. 
Sarmoko, Putri DDP, Susidarti RA, et al (2014). Increasing sensitivity of MCF-7/DOX cells towards doxorubicin by hesperetin through suppression of P-glycoprotein expression. Indonesian J Pharm, 24, 84-90.

Setiawati A, Riswanto FOD, Yuliani SH, et al (2014). Anticancer activity of mangosteen pericarp dry extract against MCF7 breast cancer cell line through estrogen $\alpha$ receptor. Indonesian J Pharm, 24, 119-24.

Siwon J (1982). A pharmacognostical study of some Indonesian medicinal plants of the family menispermaceae. PhD Thesis. Leiden University. Leiden.

Spangenberg B (2008). Derivatization, detection (quantification), and identification of compounds online. in waksmundzkaHajnos M, Sherma J, Kowalska T (eds). Thin Layer Chromatography in Phytochemistry. CRC Press. Florida.

Ueda JY, Takagi M, Shin-ya K (2009). Aminocaprophenone and pyrrolidine-type alkaloids from the leaves of ficus septica. J Nat Prod, 72, 2181-3.

Wu PL, Rao KV, Su CH, et al (2002). Phenantroindolizidine alkaloids and their cytotoxicity from the leaves of ficus septica. Heterocycles, 57, 2401-08.

Yang CW, Chen WL, Wu PL, et al (2006). Anti-inflammatory mechanisms of phenanthroindolizidine alkaloids. $\mathrm{Mol}$ Pharmacol, 69, 749-58. 